\title{
Uptake and Incorporation of Dissolved Amino Acids by Interstitial Turbellaria and Polychaeta and Their Dependence on Temperature and Salinity
}

\author{
D. Tempel and W. Westheide* \\ II. Zoologisches Institut der Universität Göttingen, Berliner Straße 28, D-3400 Göttingen, Federal Republic of Germany
}

\begin{abstract}
Interstitial meiofauna turbellarians (Haplogonaria syltensis, Nematoplana coelogynoporoides) and polychaetes (Trilobodrilus axi, Hesionides arenaria) from surf-beaten sand beaches are able to absorb dissolved ${ }^{14} \mathrm{C}$-labelled glycine and $a$ aminoisobutyric acid. In contrast, absorption by the copepod Rhizothrix gracilis is negligible. Uptake has been confirmed by autoradiographic studies, liquid scintillation counting of labelled and combusted animals, and by measurement of the incorporation of labelled glycine into proteins of the animals investigated. The nutritional profit of the absorbed glycine seems to be small: between $2 \%$ and $8 \%$ of the energy requirement of Hesionides arenaria. Nevertheless, the significance of the amino acids taken up by these soft-bodied species can be presumed because the uptake systems function optimally under conditions similar to those in the natural environment. Glycine uptake rates are highest at salinities of 30 to $35 \%$ in $H$. syltensis, in $N$. coelogynoporoides and $H$. arenaria. In $T$. axi uptake rates are higher, beyond this range, a fact corresponding to the higher salinity resistance of this species. Glycine uptake is positively correlated with increasing temperature, attaining maxima at $20^{\circ}$ and $25^{\circ} \mathrm{C}$, respectively. In winter, total absorption rates are strikingly higher than in summer. This demonstrates season-specific capacity adaptation with almost ideal compensation in $N$. coelogynoporoides and supraoptimal compensation in $T$. axi, and corresponds to prevailing temperatures in the natural habitat.
\end{abstract}

\section{INTRODUCTION}

Absorption of extremely low concentrations of dissolved free amino acids, sugars and fatty acids occurring in sea water is 'a wide-spread phenomenon among soft-bodied invertebrates' (West et al., 1977). A variety of species of nearly all major phyla - whole animals as well as isolated parts - are able to take up these nutritional compounds across their integument against high concentration gradients (for reviews consult Jørgensen, 1976; Sepers, 1977; Stewart, 1979). Only arthropods with their chitinous exoskeletons are probably incapable of accumulating dissolved organic matter (but see Gyllenberg and Lundqvist, 1978).

The nutritional significance of this active absorption process is far from being fully understood. Obviously, dissolved organic matter for most of the species can only be considered as a supplemental nutritional source (Jørgensen, 1976; Siebers and Bulnheim, 1977; West et al., 1977). Even in Pogonophora, which have no

- Addressee for reprint requests internal digestive systems, considerable difficulties still exist in explaining nutrition only in terms of taking up the dissolved organic compounds available in the surrounding medium (Southward et al., 1979). Ambient concentrations of these compounds are in general, not high enough to provide the minimum needed to sustain life. This is particularly true for the amount of dissolved organic substances in the free water. In interstitial biotopes, often densely populated by a high number of individuals and species of a special meiofauna community (Schmidt, 1969), considerably higher levels of dissolved organic matter have been reported. Nutritional uptake and trophic relations of these interstitial communities are so far little understood. In many species neither the type of food nor the mode of feeding could be determined. Individual species were seldom or never found to contain formed particles in their alimentary tracts. This fact, together with the ascertainable high concentrations of dissolved substances in pore water, encouraged an investigation of the uptake of dissolved amino acids in typical meiofauna organisms found in the interstitial habitat. 
Four frequently encountered, characteristic softbodied forms of the groups Turbellaria and Polychaeta were investigated as to their ability to absorb and incorporate dissolved labelled glycine. In considering the wide amplitude of exogenous factors in the tidal habitat of these animals special attention was given to the dependence of amino acid uptake on various temperatures and salinities at different seasons.

\section{MATERIAL AND METHODS}

Species investigated. Haplogonaria syltensis Dörjes (Acoela, Turbellaria), length $1 \mathrm{~mm}$, width $200 \mu \mathrm{m}$; Nematoplana coelogynoporoides Meixner (Proseriata, Turbellaria), length 2-3 mm, width $200 \mu \mathrm{m}$; Trilobodrilus axi Westheide (Dinophilidae, Polychaeta), length $1 \mathrm{~mm}$, width $100 \mu \mathrm{m}$; Hesionides arenaria Friedrich (Hesionidae, Polychaeta), length 1-2 mm, width $100 \mu \mathrm{m}$. Rhizothrix gracilis (T. Scott) (Harpacticoidea, Copepoda), length $0.5 \mathrm{~mm}$, width $70 \mu \mathrm{m}$ was only examined for comparative purposes. Ecological data of these species can be found in Westheide (1967), Ax (1969), Schmidt (1969), Faubel (1976), Mielke (1976). Sand samples with living animals were transported to Göttingen in thermos containers. Extraction was performed employing the seawater ice method. All animals were maintained at $15^{\circ} \mathrm{C}$ not longer than $6 \mathrm{~d}$ prior to experiments. Individuals of more or less identical dimensions were chosen for all investigations.

Measurement of free amino acids. Primary amines in surface and interstitial water were estimated by fluorometric measurement with fluorescamine (Sigma). Seawater samples were collected from the habitat of the species investigated on the Island of Sylt, North Sea (semilotic sand beach near the Harbor Laboratory of the Biologische Anstalt Helgoland), filtered through a $0.2 \mu \mathrm{m}$ membranefilter and frozen within $6 \mathrm{~h}$ of collection. Samples were treated and fluorescence was measured as described by North (1975).

A utoradiography. The test individuals were incubated at $15^{\circ} \mathrm{C}$ in sterile conic glass vials in $0.1 \mathrm{ml}$ seawater $\left(27 \%\right.$ S) with dissolved ${ }^{3} \mathrm{H}$-glycine (Amersham-Buchler, Wenden/Braunschweig) $\left(20 \mu \mathrm{mol} l^{-1}\right.$; $\left.1 \mu \mathrm{Ci} \mathrm{ml} \mathrm{ml}^{-1}\right)$. Streptomycin $\left(50 \mu \mathrm{g} \mathrm{ml}^{-1}\right)$ was added to reduce microbial activity. In these and subsequent investigations, aged, carefully filtered, natural seawater was utilized. The quantity of naturally occurring amino acids was not determined, yet can be considered insignificant in view of the long storage period (see Bohling, 1970; Siebers, 1976). After incubation periods of $15 \mathrm{~min}, 30 \mathrm{~min}, 1 \mathrm{~h}, 2 \mathrm{~h}, 4 \mathrm{~h}, 8 \mathrm{~h}, 12 \mathrm{~h}, 16 \mathrm{~h}, 20 \mathrm{~h}$ and
$26 \mathrm{~h}$ the individuals were rinsed in seawater with inactive glycine $\left(20 \mu \mathrm{mol} \mathrm{1}^{-1}\right)$ and treated as follows: After fixation for $90 \mathrm{~min}$ in $2.5 \%$ buffered glutaraldehyde they were rinsed 5 times in cacodylate buffer overnight. Fixation in $1 \%$ osmiumtetroxide for $90 \mathrm{~min}$ followed. After dehydration in acetone and propylenoxide specimens were embedded in araldite. Individual semi-thin sections $(0.5 \mu \mathrm{m})$ were placed on slides previously dipped in gelatine solution, followed by direct application of Kodak AR 10 stripping film, after soaking the film emulsion strips in an ice-cold sucrose solution. After an exposure period of $63 \mathrm{~d}$ at $4{ }^{\circ} \mathrm{C}$, as determined by trial development and calculated according to Wainwright et al. (1954), the film was developed in Kodak D 19.

Liquid scintillation counting of absorbed amino acids. Definite numbers of specimens $(n=5-22)$ were incubated in $0.1 \mathrm{ml}$ seawater with ${ }^{14} \mathrm{C}$-glycine (Amersham-Buchler, Wenden/ Braunschweig) and streptomycin $\left(50 \mu \mathrm{g} \mathrm{ml} \mathrm{m}^{-1}\right)$. In certain experimental series puromycin $\left(2 \mathrm{mmol} \mathrm{l}^{-1}\right)$ was added. Incubation periods $(30 \mathrm{~min}$ to $36 \mathrm{~h})$, salinities (10 to $40 \% \mathrm{~S}$ ), temperatures $\left(1^{\circ}\right.$ to $30^{\circ} \mathrm{C}$ ) and glycine concentrations (20 to $120 \mu \mathrm{mol} \mathrm{l}^{-1}$ ) were modified. Most experiments were carried out at a concentration of $20 \mu \mathrm{mol} \mathrm{l}^{-1}\left(16 \mathrm{nCi} 0.1 \mathrm{ml}^{-1}\right)$. At the end of each experiment the specimens were rinsed three times in seawater containing $20 \mu \mathrm{mol} \mathrm{l}^{-1}$ unlabelled glycine and transferred to distilled water. Directly thereafter they were blotted on filter paper and dried at $60^{\circ} \mathrm{C}$. Then the filters with the specimens adhering were combusted in Lexan capsules in an Intertechnique N 4101 C. S. sample oxidizer. The counting solution contained phenylethylamine $330 \mathrm{ml}$, methanol $220 \mathrm{ml}$, toluol 400 $\mathrm{ml}$, aqua dest. $75 \mathrm{ml}$, PPO $7 \mathrm{~g}$, bis-MSB $0.7 \mathrm{~g}$. Radioactivity was counted in a Philips liquid scintillation analyzer PW 4510. Dpm-values of individual samples were corrected by subtracting the radioactivity of the distilled water used to transfer the specimens onto the filter paper, the blank rate of the counter, and the experimentally derived activity remaining on the epidermis. This corrected value was converted to $\mu \mathrm{mol}$ of substrate per gram wet weight of the different species.

Accumulation of $\alpha$-aminoisobutyric acid was investigated by incubation for $16 \mathrm{~h}$ in seawater $(27 \% \mathrm{~S}$ $\left.15^{\circ} \mathrm{C}\right)$ with ${ }^{14} \mathrm{C}$ - $\alpha$-AIB $\left(20 \mu \mathrm{mol} l^{-1}, 25 \mathrm{nCi} 0.1 \mathrm{ml}^{-1}\right.$; streptomycin $50 \mu \mathrm{g} \mathrm{ml}^{-1}$ ). The animals were then rinsed in seawater with inactive $\alpha$-AIB and dissolved in $0.5 \mathrm{ml}$ Digestin $\left(2 \mathrm{~h}, 60^{\circ} \mathrm{C}\right)$. The undissolved portions were centrifuged and the supernatant measured in $10 \mathrm{ml}$ Bray scintillation solution. The concentration of $\alpha$-AIB in the body water of a specimen was calculated with the assumption that $80 \%$ of the wet weight is water (Schmitt 1955). 
Incorporation of ${ }^{14} \mathrm{C}-\mathrm{gly}$ cine into proteins. The following incubation media were used: (1) $0.1 \mathrm{ml}$ seawater with ${ }^{14} \mathrm{C}$-glycine and streptomycin (50 mg $100 \mathrm{ml}^{-1}$ ); (2) $0.1 \mathrm{ml}$ seawater with ${ }^{14} \mathrm{C}$-glycine, streptomycin and puromycin $\left(90 \mathrm{mg} 100 \mathrm{ml}^{-1}\right) ;$ (3) 0.1 $\mathrm{ml}$ seawater with ${ }^{14} \mathrm{C}$-glycine, streptomycin and cycloheximid ( $2.5 \mathrm{mg} 100 \mathrm{ml}^{-1}$ ). In all experiments: concentration of glycine $20 \mu \mathrm{mol} \mathrm{l}^{-1}$, incubation period 16 h, salinity $27 \% \mathrm{~S}$, temperature $15^{\circ} \mathrm{C}$, number of specimens per trial $\mathrm{n}=30-250$. Working procedure according to Beckmann (1972): Following incubation, the specimens were rinsed three times in seawater containing $20 \mu \mathrm{mol} \mathrm{l}^{-1}$ unlabelled glycine. Thereafter homogenization with $0.1 \mathrm{ml}$ ice-cold $0.25 \mathrm{M}$ sucrose solution $(0.006 \mathrm{~N} \mathrm{NaOH})$ and addition of $0.1 \mathrm{ml}$ icecold perchloric acid $(60 \%)$ to dissolve acid soluble material; $15 \mathrm{~min}$ agitation at $0{ }^{\circ} \mathrm{C}$; addition of $0.5 \mathrm{ml}$

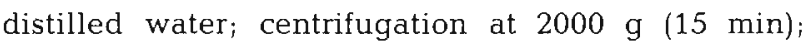
decanting of the supernatant and addition of $0.2 \mathrm{ml}$ distilled water and $0.1 \mathrm{ml} 1 \mathrm{~N} \mathrm{NaOH}$; agitation at $37^{\circ} \mathrm{C}$ for $15 \mathrm{~min}$; addition of $0.8 \mathrm{ml}$ Digestin to dissolve proteins; agitation at $60^{\circ} \mathrm{C}$ for $2 \mathrm{~h}$. Activity was measured after addition of $10 \mathrm{ml}$ Bray scintillation solution.

Determination of dry and wet weight. Living animals were measured under the microscope. The wet weights were calculated assuming a cylindrical shape and a specific gravity of $1.1 \mathrm{mg} \mathrm{mm}^{-3}$ (Stripp, 1969): Haplogonaria syltensis $\left(2.20 \times 10^{-5} \mathrm{~g}\right)$, Nematoplana coelogynoporoides $\left(11.00 \times 10^{-5} \mathrm{~g}\right)$, Trilobodrilus axi $\left(0.56 \times 10^{-5} \mathrm{~g}\right)$ and Hesionides arenaria $\left(0.87 \times 10^{-5} \mathrm{~g}\right)$. Dry weights were determined assuming a water content of $80 \%$. Experimentally derived weights of these four species were higher than the hypothetically calculated values, with the exception of $N$. coelogynoporoides, in which both values corresponded. Adhering particles may have contributed to this discrepancy; hence the experimental values were not applied.
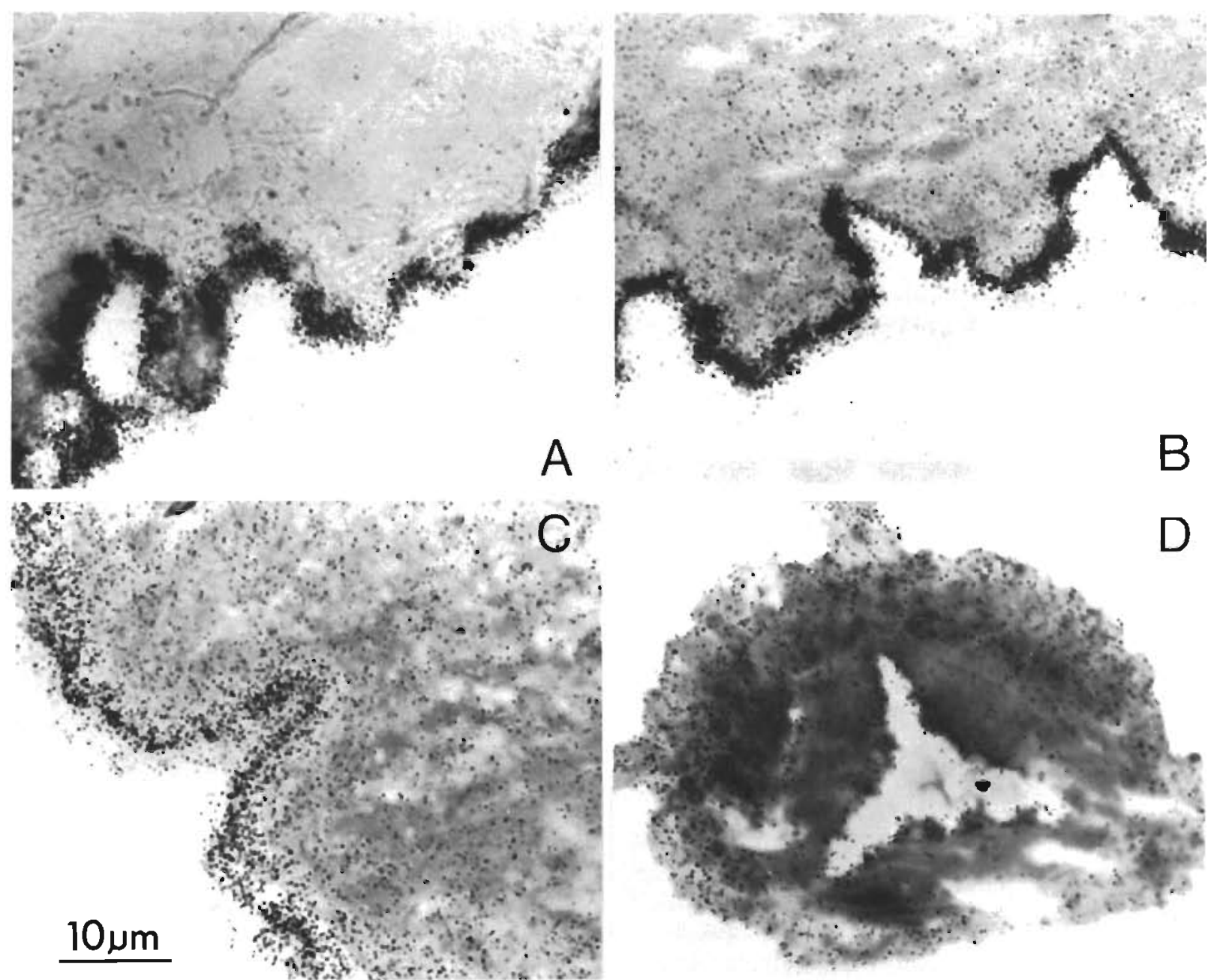

Fig. 1. Autoradiographs. A-C Sagittal sections of Trilobodrilus axi; dorsal body surface points upwards. D Cross section in the pharynx region of Hesionides arenaria. Density and distribution of grains after incubations for $1 \mathrm{~h}(\mathrm{~A}), 4 \mathrm{~h}(\mathrm{~B}), 8 \mathrm{~h}(\mathrm{D}) \mathrm{and} 20 \mathrm{~h}(\mathrm{C})$ in $20 \mu \mathrm{mol} \mathrm{l}^{-1}{ }^{3} \mathrm{H}$-glycine $\left(1 \mu \mathrm{Ci} \mathrm{ml}{ }^{-1}\right)$ at $15{ }^{\circ} \mathrm{C}$ and $27 \% \mathrm{~S}$. D stained in toluidineblue 


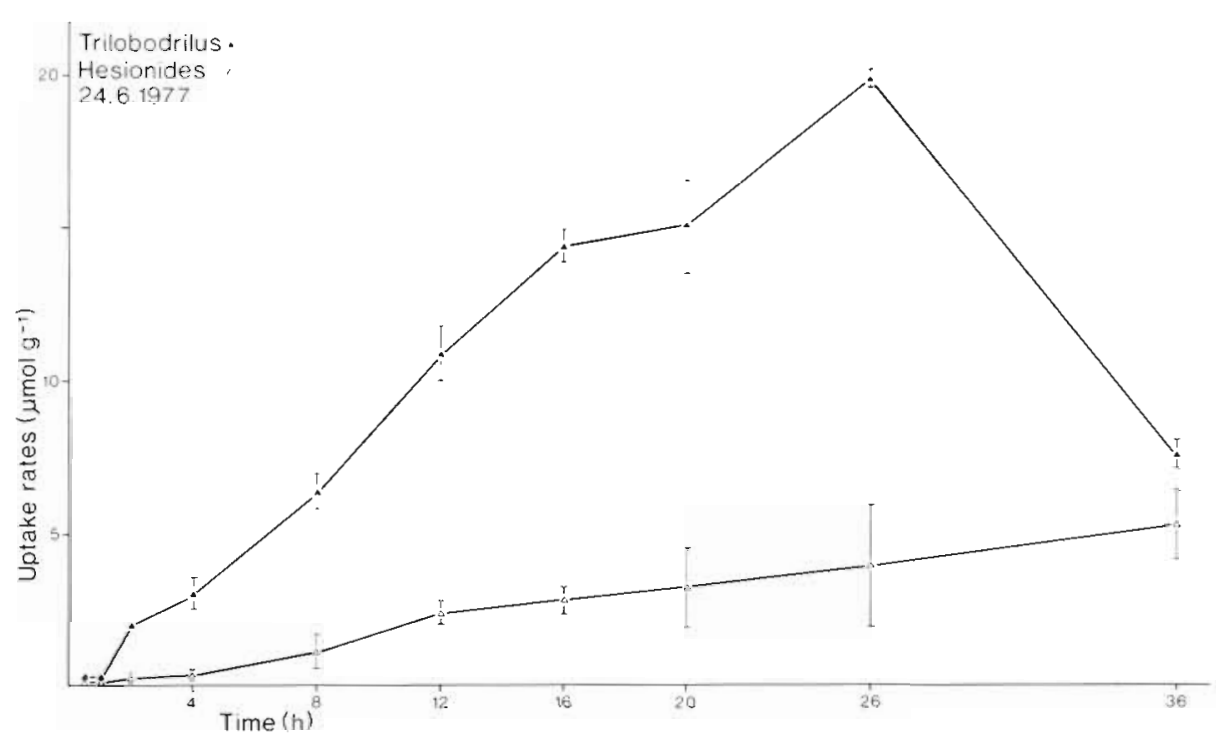

Fig. 2. Dependence of ${ }^{14} \mathrm{C}$-glycine uptake on incubation period in Trilobodrilus axi $(\Delta)$ and Hesionides arenaria ( $\Delta$ ). Initial glycine concentration: $20 \mu \mathrm{mol} \mathrm{l} \mathrm{l}^{-1}$; salinity: $27 \% \mathrm{~S}$; temperature: $15^{\circ} \mathrm{C}$. Vertical bars represent standard deviations from a sample number of 3

\section{RESULTS}

\section{Uptake and Incorporation of Dissolved Amino Acids}

Autoradiographs of sagittal and cross sections of Nematoplana coelogynoporoides, Trilobodrilus axi, and Hesionides arenaria confirm the uptake of dissolved ${ }^{3} \mathrm{H}$-glycine across the body surface and its distribution throughout most parts of the body. The increasing number of grains visible after longer periods of incubation and their progressive inward distribution indicate continuous incorporation (Fig. 1). Additional absorption through the digestive tract by drinking cannot be definitely excluded from these autoradiographs. The absorption demonstrated in the pharynx of $H$. arenaria (Fig. 1D) is not necessarily an indication of internal ingestion however, since this deals structurally with an external epithelium (Westheide and Rieger, 1978).

Scintillation measurements of combusted specimens show that uptake rates in all four soft-bodied species strictly depend on the period of incubation (Fig. 2). The maximum glycine absorption, at an initial ambient concentration of $20 \mu \mathrm{mol} \mathrm{l} \mathrm{l}^{-1}\left(15^{\circ} \mathrm{C}\right)$ occurred after $20 \mathrm{~h}$ in Haplogonaria syltensis, after $20-26$ h in Nematoplana coelogynoporoides and Trilobodrilus axi. In Hesionides arenaria a constant linear increase in body ${ }^{14} \mathrm{C}$-glycine concentration was observed over an incubation period of $36 \mathrm{~h}$. Simultaneous counting of specimens and incubation medium showed (Fig. 3) that this decrease cannot be attributed to subsequent loss of absorbed label into the medium. These curves rather indicate that a considerable portion of absorbed ${ }^{14} \mathrm{C}$ glycine was respired as ${ }^{14} \mathrm{CO}_{2}$. Generally the curves demonstrate active concentration of labelled glycine in these soft-bodied species. The copepod Rhizothrix gracilis, in contrast, takes up only a small amount of labelled glycine: in winter after $16 \mathrm{~h}\left(15^{\circ} \mathrm{C}, 27 \% \mathrm{~S}\right)$ : $0.44 \mu \mathrm{mol} \mathrm{g} \mathrm{g}^{-1}$ (in comparison $N$. coelogynoporoides: $2.60 \mu \mathrm{mol} \mathrm{g}{ }^{-1}$, T. axi: $19.91 \mu \mathrm{mol} \mathrm{g}{ }^{-1}$ ).
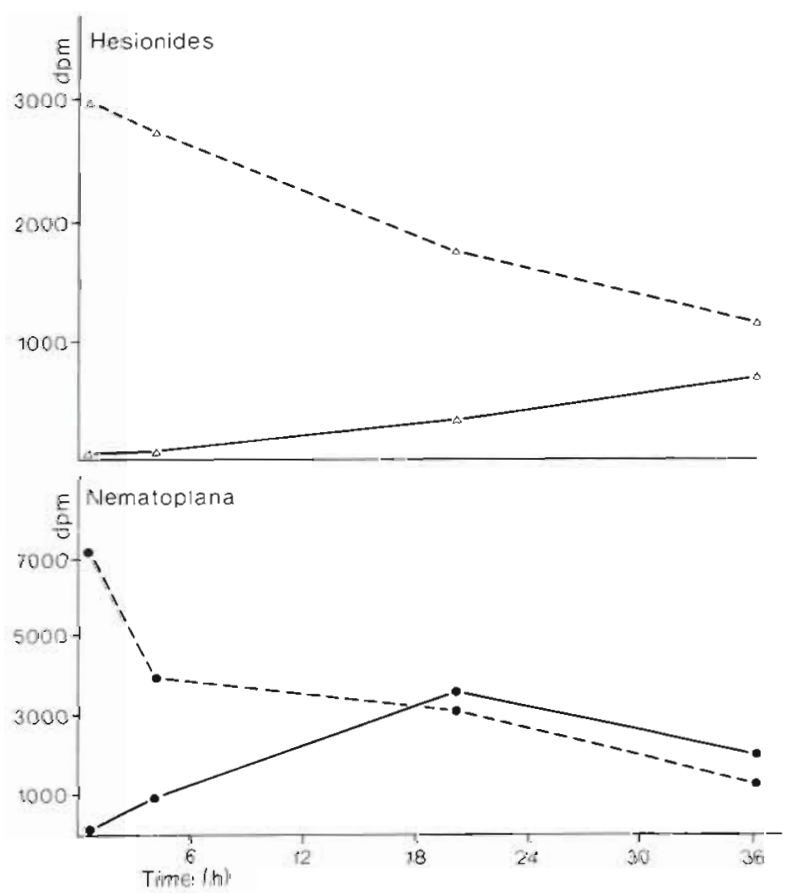

Fig. 3. Synchronous activity changes ( $\mathrm{dpm}$ ) in the incubation medium (broken line) and in incubated animals (solid line) converted for individuals. Initial ${ }^{14} \mathrm{C}$-glycine concentration:

$20 \mu \mathrm{mol} \mathrm{l} \mathrm{l}^{-1}$; salinity: $27 \% \mathrm{~S}$; temperature: $15^{\circ} \mathrm{C}$ 
Table 1. Concentration of labelled $\alpha$-AIB in the animals compared with the incubation medium. Incubation period: 16 $\mathrm{h}$; salinity: $27 \% \mathrm{~S}$; temperature: $15^{\circ} \mathrm{C}$; initial concentration of $\alpha$-AIB: $20 \mu \mathrm{mol} \mathrm{I}^{-1}$; number of individuals in each sample: $40-140$; number of samples: $4-5$

\begin{tabular}{|lccc|}
\hline Species & $\begin{array}{c}\text { Uptake } \\
(\text { nmol g }\end{array}$ & $\begin{array}{c}\text { Standard } \\
\text { deviation }\end{array}$ & $\begin{array}{c}\text { Concentra- } \\
\text { tion factor }\end{array}$ \\
\hline H. syltensis & 347 & 53 & 74 \\
N. coelogynoporoides & 91 & 25 & 4 \\
T. axi & 214 & 53 & 182 \\
H. arenaria & 113 & 37 & 62 \\
\hline
\end{tabular}

Table 2. Incorporation of ${ }^{14} \mathrm{C}$-glycine $\left(20 \mu \mathrm{mol} \mathrm{I}^{-1}\right)$ in protein. Incubation period: $16 \mathrm{~h}$; salinity: $27 \%$ S; temperature: $15^{\circ} \mathrm{C} ;$ number of individuals in each sample: 50-250. Additional values for total uptake, derived from an independent experiment carried out under the same conditions, are shown for comparison

\begin{tabular}{|lccc|}
\hline Species & $\begin{array}{c}\text { Total } \\
\text { uptake } \\
\left(\mathrm{nmol} \mathrm{g}^{-1}\right. \\
\text { wet } \\
\text { weight) }\end{array}$ & $\begin{array}{c}{ }^{14} \text { C-glycine } \\
\text { incorporated } \\
\text { in proteins } \\
\text { (nmol g }\end{array}$ & $\begin{array}{c}\% \\
\text { wet weight) } \\
\text { incor- } \\
\text { porated }\end{array}$ \\
\hline H. syltensis & 1380 & 92 & 6.6 \\
N. coelogynoporoides & 1796 & 56 & 3.1 \\
T. axi & 14391 & 55 & 0.4 \\
H. arenaria & 2817 & 256 & 9.1 \\
\hline
\end{tabular}

The existence of an active transport system was confirmed also by the uptake of $\alpha$-aminoisobutyric acid (Table 1). This process also renders net uptake quite probable. The artificial non-metabolizable amino acid had been concentrated in the animais after a $16 \mathrm{~h}$ uptake period in 4 to 182 -fold concentrations compared with the incubation medium.

Measurements of isolated proteins in both turbellarians and polychaetes displayed radioactivity after incubation in ${ }^{14} \mathrm{C}$-glycine (Tab. 2). Following addition of protein synthesis inhibitors (puromycin, cycloheximid) the values were reduced. This was also the case in measurements of activity in other uptake experiments (data not presented here). Compared to the total uptake, activity in isolated proteins is relatively small. A large portion of the absorbed glycine probably remained in the free amino acid pool of the animals.

\section{Salinity Dependence of ${ }^{14} \mathrm{C}$-glycine Uptake}

Figure 4 presents data on uptake of dissolved ${ }^{14} \mathrm{C}$ glycine in relation to different salinity values of the incubation medium. Haplogonaria syltensis, Nematoplana coelogynoporoides and Hesionides arenaria

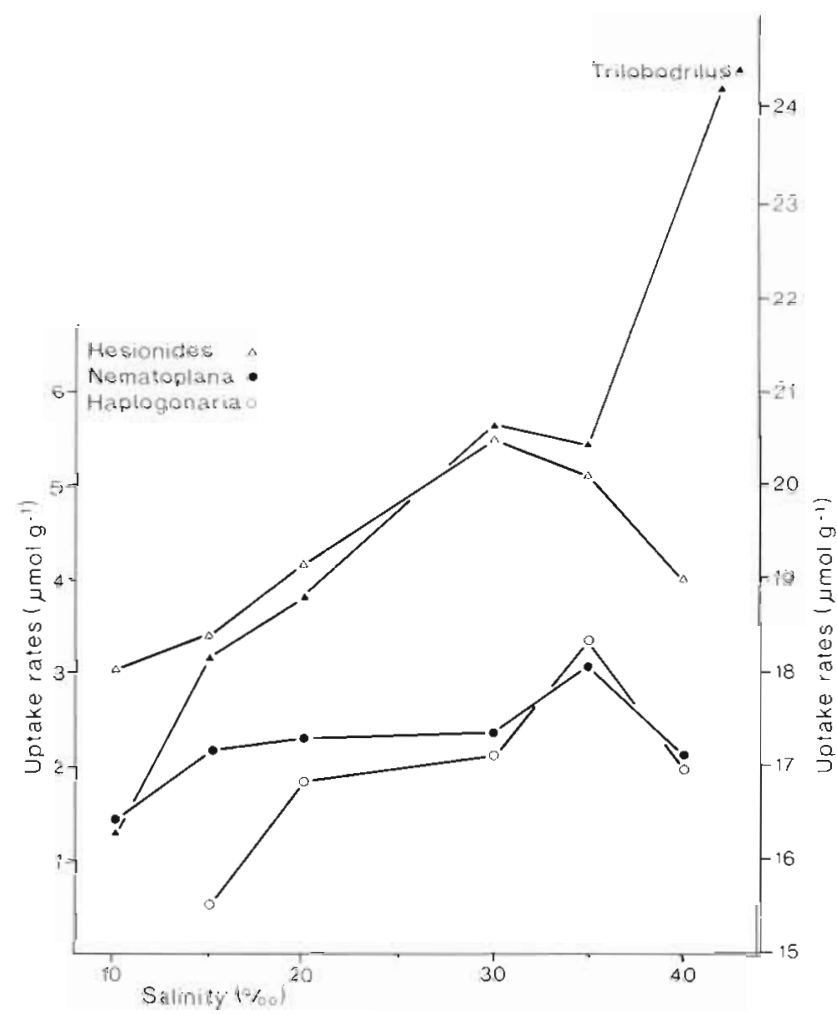

Fig. 4. Uptake of ${ }^{14} \mathrm{C}$-glycine as a function of salinity. Initial concentration in medium: $20 \mu \mathrm{mol} \mathrm{l^{-1 }}$; incubation period: $16 \mathrm{~h}$; temperature: $15^{\circ} \mathrm{C}$. Right scale values only for Trilobodrilus axi. Standard deviations omitted for clarity

show the highest uptake rates at 30 or $35 \%$. For Trilobodrilus axi the maximum value is attained at or above $40 \%$. Glycine uptake was $300 \%$ (H. syltensis), $5 \%$ ( N. coelogynoporoides), $11 \%$ (T. axi), and $63 \%$ (H. arenaria) higher at $30 \%$ than at $15 \% \mathrm{~S}$ (experiments conducted in June). A similar salinity dependence is observed in experiments carried out in winter.

\section{Temperature Dependence of ${ }^{14} \mathrm{C}$-glycine Uptake}

Uptake rates are clearly temperature dependent - in cold-acclimated individuals in winter, as well as in warm-acclimated individuals collected in summer. The curves derived from experiments conducted in summer and winter show maxima at $20^{\circ}$ or $25^{\circ} \mathrm{C}$ for Nematoplana coelogynoporoides, Trilobodrilus axi and Hesionides arenaria (Fig. 5). At $30^{\circ} \mathrm{C}$, the uptake rate is already reduced in summer. $\mathrm{Q}_{10^{-v}}$ alues (rate at $20^{\circ} \mathrm{C}$ /rate at $10^{\circ} \mathrm{C}$ ) in June are 1.8 in $N$. coelogynoporoides, 1.2 in $T$. axi, and 2.0 in $H$. arenaria. Coldacclimated animals characteristically display a significantly higher absorption than warm-acclimated ones under the same experimental temperature conditions ( N. coelogynoporoides, $T$. axi, H. arenaria). A compari- 


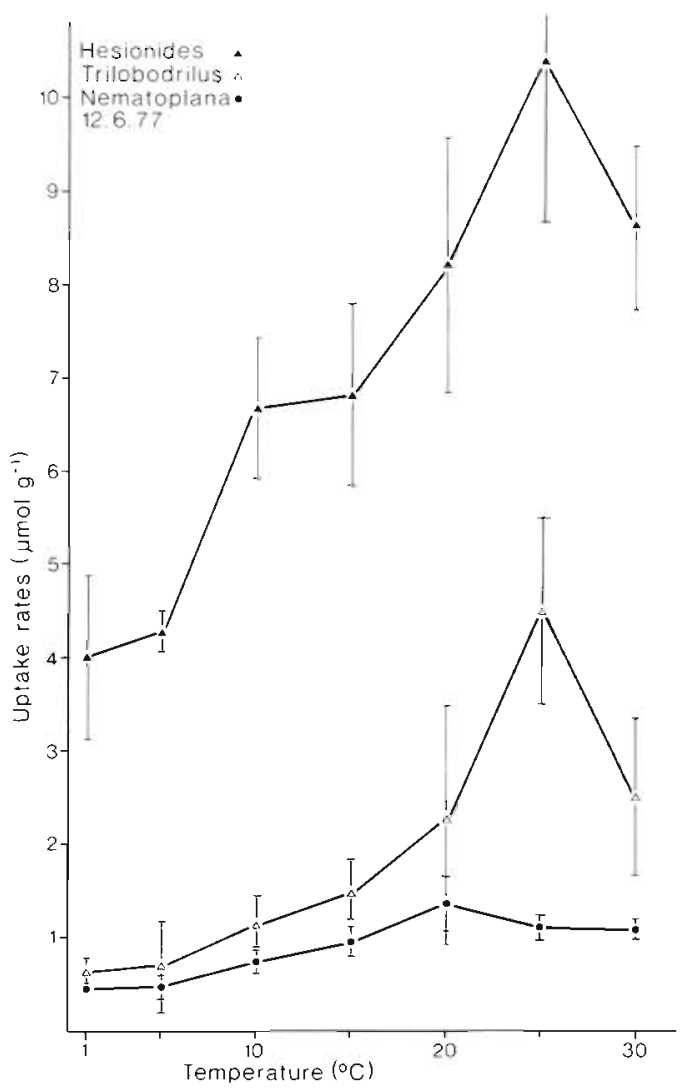

Fig. 5. Dependence of ${ }^{14} \mathrm{C}$-glycine uptake on temperature. Initial glycine concentration in the medium: $20 \mu \mathrm{mol} \mathrm{l}^{-1}$; incubation period: $16 \mathrm{~h}$; salinity: $27 \% \mathrm{~S}$. Vertical bars: standard deviations from a sample number of 3 or 4

son of absorption rates at $15^{\circ} \mathrm{C}$ illustrates this difference particularly well (Figs 6, 7, 8). Winter uptake rates are about 2 or 3 times higher than summer values.

\section{DISCUSSION}

Dissolved amino acid absorption by interstitial Turbellaria and Polychaeta, and DAA contribution to the metabolic requirements of these animals are indicated by autoradiographic studies as well as by significant temperature effects on uptake rates, uptake of $\alpha$-AIB and incorporation of labelled glycine into proteins of the soft-bodied animals tested. Although even $\alpha$-AIBexperiments may not necessarily permit us to conclude a real net influx of these substances (see discussion in Stewart, 1979), such net influx has been demonstrated in other species (Stephens, 1975; Siebers and Bulnheim, 1977) and is now generally accepted for a large number of soft-bodied marine animals.

As indicated by the autoradiographs, this uptake occurs primarily across the body surface. Uptake across the alimentary tract cannot be absolutely excluded by

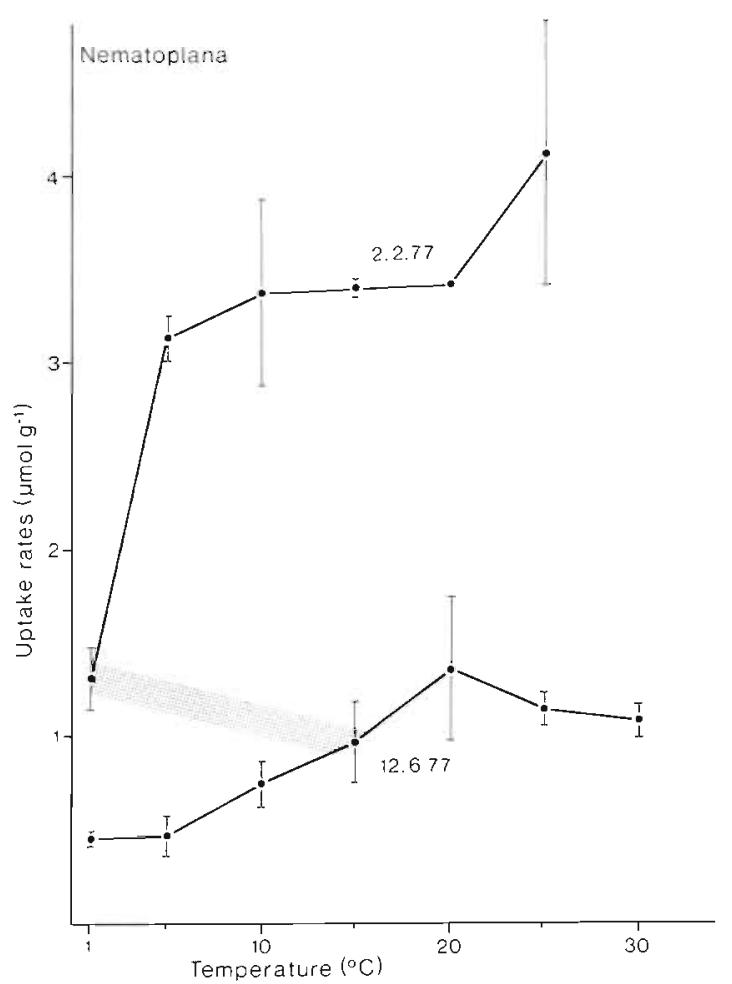

Fig. 6. Dependence of ${ }^{14} \mathrm{C}$-glycine uptake on temperature and season. Initial glycine concentration in the medium: $20 \mu \mathrm{mol}$ $\mathrm{l}^{-1}$; incubation period: $16 \mathrm{~h}$; salinity: $27 \% \mathrm{~S}$; experiments conducted in February and June for Nematoplana coelogynoporoides. Vertical bars: standard deviations from a sample number of 4 . Dotted bar connects values of real temperatures in February and June

our investigations; however, for other organisms - in particular for annelids - this mode of uptake was disproved (Taylor, 1969; Ahearn and Gomme, 1975). Correlation between uptake rates and body weights in the four soft-bodied species investigated (Fig. 9) shows that uptake is a body-surface related phenomenon (Virkar, 1963; Stephens, 1964; Sepers, 1977). Absorption across the body surface is probably structurally enhanced by the complete lack of, or by an only delicate cuticle penetrated by microvilli (Chien et al., 1972; Schlichter, 1973). The epithelial tissues of the species studied here show no great structural barriers against nutrient influx. The Turbellaria generally possess no cuticle, but rather an epidermis with a surface area enlarged by microvilli (Bedini and Papi, 1974). Hesionides arenaria and the genus Trilobodrilus have a relatively thin cuticle penetrated by numerous microvilli (Westheide and Rieger, 1978; Rieger and Rieger, 1976). Dense cuticular layers, however, inhibit or impede nutrient transport in Crustacea and Chelicerata (Stephens and Schinske, 1961). Our few experiments conducted with the copepod Rhizothrix gracilis confirm this. In contradiction to this are the 


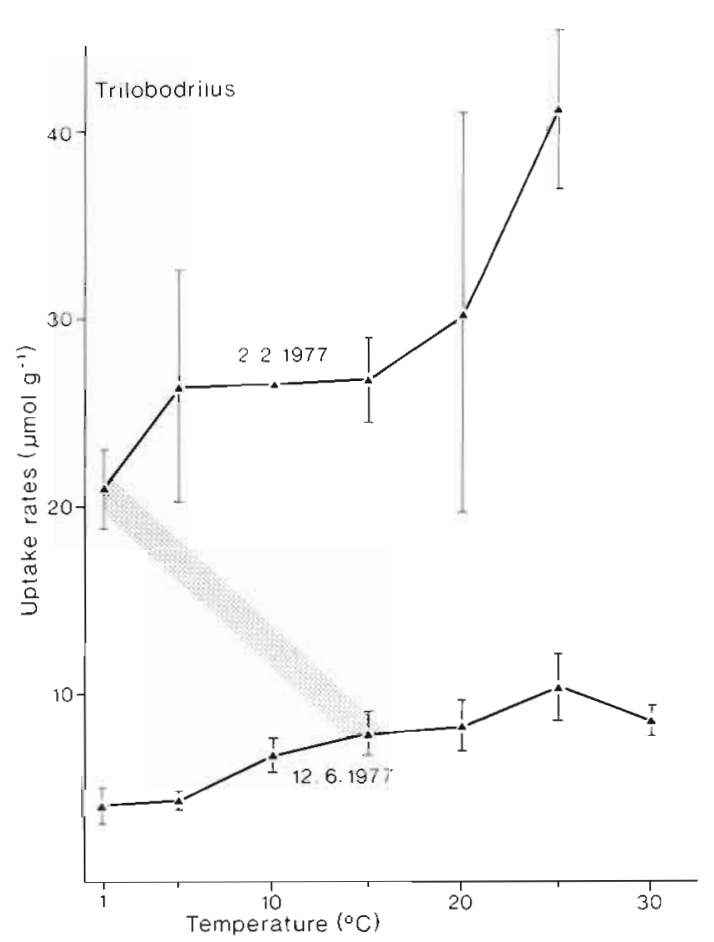

Fig. 7. Dependence of ${ }^{14} \mathrm{C}$-glycine uptake on temperature and season. Initial glycine concentration in the medium: $20 \mu \mathrm{mol}$ $\mathrm{l}^{-1}$, incubation period: $16 \mathrm{~h}_{\text {; }}$ salinity: $27 \% \mathrm{~S}_{\text {; }}$ experiments conducted in February and June for Trilobodrilus axi. Vertical bars: standard deviations from a sample number of 4 . Dotted bar connects values of real temperatures in February and June

findings of Gyllenberg and Lundqvist (1978) which point toward an uptake of dissolved glucose in the two copepods Cyclops oithonoides and Arthrobacter sp.

A quantitative estimation of the contribution of absorbed glycine to metabolic requirements and its nutritional significance can only be made here for Hesionides arenaria. The metabolic rate of this species lies between 200 and $800 \mu 0_{2} \mathrm{~g}^{-1} \mathrm{~h}^{-1}$ depending on the oxygen concentration in the medium (Lasserre and Renaud-Mornant, 1973). A calculation of the energy gain (to metabolize 1 mole of glycine 1.5 moles of $\mathrm{O}_{2}$ are required) at the lowest $\mathrm{O}_{2}$-value yields a nutritional profit of glycine absorption between about $2 \%$ (for June) and $8 \%$ (for October) - without considering the energy demand for active transport. These values lie within the range of measurements recently calculated by Siebers and Bulnheim (1977) for Enchytraeus albidus in the same manner. The actual energetic profit, however, is probably slightly higher, since the oxygen uptake of $\mathrm{H}$. arenaria was determined at $19^{\circ} \mathrm{C}$, whereas the $\mathrm{O}_{2}$-uptake data used here were derived at $15^{\circ} \mathrm{C}$.

Even with this somewhat more optimistic view, the expectation would still not be fulfilled, that true interstitial meiofauna organisms utilize a greater propor-

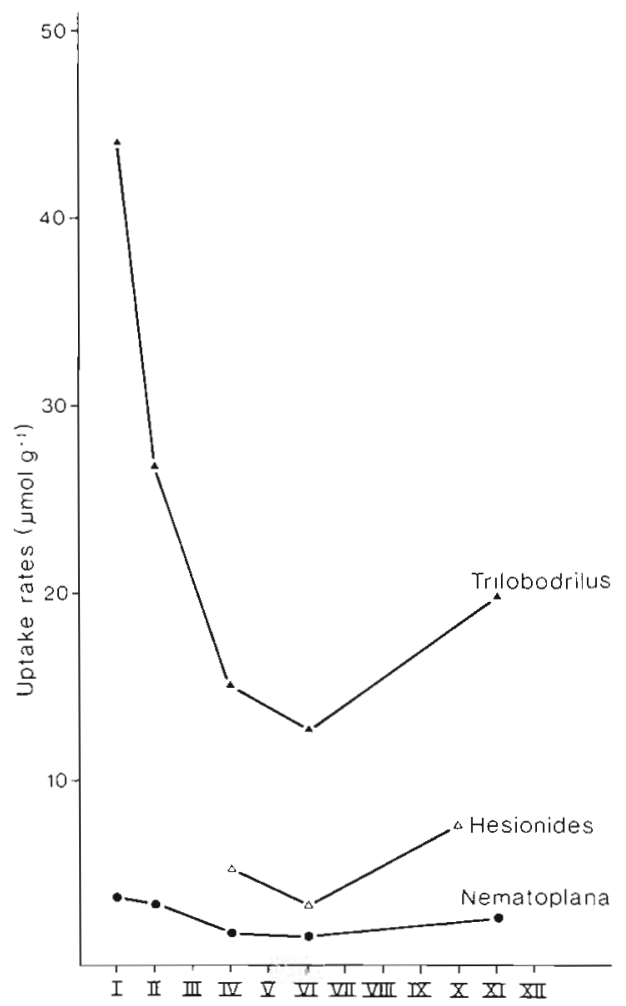

Fig. 8. Uptake of ${ }^{14} \mathrm{C}$-glycine in Nematoplana coelogynoporoides, Trilobodrilus axi and Hesionides arenaria. Average values from different experiments conducted in different months (I-XII) from 1976-1978. Initial glycine concentration in the medium: $20 \mu \mathrm{mol} \mathrm{l}^{-1}$; period of incubation: $16 \mathrm{~h}_{i}$ salinity: $27 \% \mathrm{~S}$; temperature: $15{ }^{\circ} \mathrm{C}$

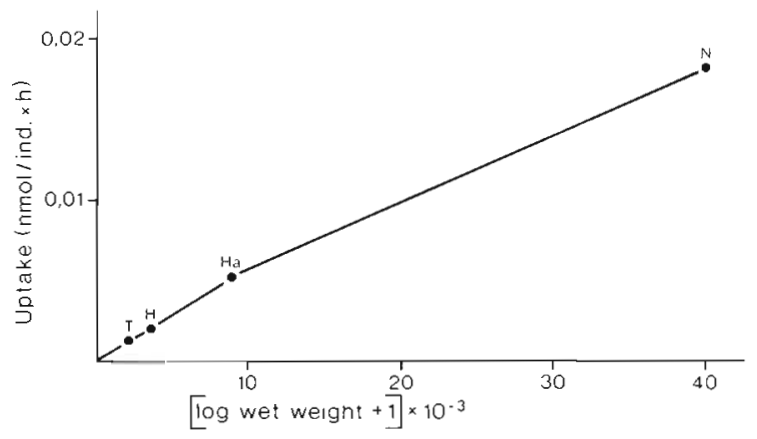

Fig. 9. Relation between ${ }^{14} \mathrm{C}$-glycine uptake and body weight in the four species studied. Ha $=$ Haplogonaria syltensis, $\mathrm{N}=$ Nematoplana coelogynoporoides, $\mathrm{T}=$ Trilobodrilus axi, $\mathrm{H}=$ Hesionides arenaria

tion of dissolved substances for metabolism than marine organisms of other biotopes. This expectation is based on two findings: Direct observations of food and feeding in many interstitial species are scarce, and some of them seldom or never contain nutrient particles in their digestive tracts. This holds true also for Hesionides arenaria. Some individuals of this species contained diatoms and foraminiferas in their alimen- 
tary canals, particularly in spring; yet the majority of the population had empty guts or revealed only small amounts of detritus when observed over a longer period of time (Westheide, 1967; Salvat and RenaudMornant, 1969). As to whether the diatoms are nutritionally utilized at all is questionable, since their cytoplasm has been shown in many cases to be fully intact even when found in the posterior gut. Other nutritional components were seldom observed. Perhaps bacteria comprise part of the diet. In any case, the individuals could be maintained for months in glass jars containing a few sand grains without being fed. Trilobodrilus axi grazes on the aufwuchs of sand grains and also feeds on suspended, fine particles (Westheide and Schmidt, 1974). Nematoplana coelogynoporoides is considered to be a predator and has also been found to contain diatoms (Sopott, 1973). Haplogonaria syltensis takes up diatoms and detritus particles; juveniles are assumed to feed on aufwuchs of sand grains (Dörjes, 1968).

The other factor accounting for a substantial nutritional contribution is the relatively high concentration of dissolved organic compounds in interstitial water. Bohling (1972) found an amino acid concentration not higher then $6 \mu \mathrm{mol} \mathrm{l}^{-1}$ (about $1.1 \mu \mathrm{mol} \mathrm{l} \mathrm{l}^{-1}$ of that being glycine) in open seawater of the North Sea. Values of other authors are mostly lower; average values published by Dawson and Pritchard (1978) amount to $0.2 \mu \mathrm{mol} \mathrm{l} \mathrm{l}^{-1}$. The concentrations in pore water of interstitial biotopes are considerably higher: up to $74 \mu \mathrm{mol}$ $\mathrm{l}^{-1}$ ninhydrin-positive material, including $10 \mu \mathrm{mol} \mathrm{l}^{-1}$ glycine (Stephens, 1963); 29-103 $\mu \mathrm{mol} \mathrm{l}^{-1}$ free primary amines (Stephens, 1975); up to $20 \mu \mathrm{mol} 1^{-1}$ glycine (Henrichs and Farrington, 1979); 17-224 $\mu \mathrm{mol} \mathrm{l}^{-1}$ free primary amines, $80-85 \%$ of these amino acids (Stephens et al., 1978); $16-56 \mu \mathrm{mol} \mathrm{l^{-1 }}$ free primary amines, about $80 \%$ of these amino acids (Jørgensen, 1979).

The term 'interstitial water' must, however, be differentiated. The previously mentioned amino acid values were found in mudflats (Stephens, 1963, 1975) or in sublittoral and partly anoxic sediment layers (Henrichs and Farrington, 1979). These sediments differ markedly from the habitats of the species investigated here, i. e. coarse-grained tidal beaches (grade $6^{\circ}$ ), in which the interstitial water is exchanged during a tidal period (Meineke and Westheide, 1979), and in which dissolved substances can accumulate significantly only in deeper ground-water levels. Our own preliminary investigations of samples obtained just above the ground-water level have shown total concentrations of free primary amines only 2 to 4 times greater than those of free nearshore water. If one considers that these nearshore waters yield a higher concentration than offshore waters (see also Lee and Bada, 1977), we may assume that the total amino acid concentration in the natural environment of the species investigated is more or less of the same magnitude as our experimental ${ }^{14} \mathrm{C}$-glycine concentration, and that it is below those in the references cited above

In considering the significance of the nutritional role of absorbed amino acids, one must further keep in mind that only glycine uptake was measured in our experiments. Indeed, glycine and serine comprise the largest proportion of total amino acids in free water (Bohling, 1972; Clark et al., 1972; Schell, 1974). In interstitial water, on the contrary, other amino acids such as glutamic acid and $\beta$-amino-glutaric acid (Henrichs and Farrington, 1979) predominate. High levels of alanine and glutamic acid were reported by Stephens (1975). These amino acids were not investigated here. So we do not know the particular uptake systems of interstitial animals. Other aspects to consider would be a higher energy profit from the uptake of amino acid mixtures (Stephens, 1963; Siebers and Bulnheim, 1977) and from a simultaneous uptake of carbohydrates and fatty acids. A substantial indication of the nutritional significance of dissolved amino acids is the fact that the uptake systems function optimally under conditions which approach those encountered in the natural habitat of the species investigated.

Salinities of the habitat examined on Sylt range between $27 \%$ and $31 \% \mathrm{~S}$ (Schmidt, 1968; Westheide, 1968; Hartwig, 1973). Sunradiation at low tide sometimes leads to increased salt concentration in pore water; rainfall, in turn, causes salinity decrease. Observed maximum uptake rates between $30 \%$ and $35 \%$ S for Nematoplana coelogynoporoides, Haplogonaria syltensis and Hesionides arenaria agree closely with their accustomed environmental salinity range. Only with Trilobodrilus axi is the uptake higher. Experiments with respect to salinity tolerance (unpublished data of Scharnofske) indicate that this surface-living species is, in fact, especially resistant to high salinity. Salinity-dependent uptake of amino acids is not uncommon (Stephens, 1964; Stephens and Virkar, 1966; Shick, 1973; Siebers and Bulnheim, 1977). It has been attributed to incompatıbility between osmoregulation and accumulation of amino acids, and a direct role of $\mathrm{Na}^{+}$in the uptake system (Stephens, 1964; Siebers and Bulnheim, 1977).

The positive effect of increasing temperatures on uptake rates in the species investigated has also been reported in other marine invertebrates (Schlichter, 1974; Shick, 1975) with $Q_{10}$-values higher than in our species. The differences in uptake rates between coldand warm-acclimated individuals are particularly noteworthy. Total uptake is much higher in winter than in summer at corresponding experimental temperatures. The temperature of the free nearshore 
water in the localities of the species investigated (List) Sylt) oscillates between $-2.2^{\circ} \mathrm{C}$ and $29.5^{\circ} \mathrm{C}$ (e. g. Hartwig, 1973). Values in the tidal beaches during low tide are, as a rule, somewhat lower in winter and higher in summer. The average temperature for the periods of experimentation in February and June - the temperature to which the animals had been acclimated, and at which they would normally absorb in their natural habitat - was $0^{\circ}$ and $14{ }^{\circ} \mathrm{C}$, respectively. At these temperatures (dotted bars in the curves) summer and winter uptake rates for $N$. coelogynoporoides (Fig. 6), reveal almost identical values. This is not the case for Trilobodrilus axi (Fig. 7), although its uptake rates for summer and winter approach one another with respect to the naturally occurring temperatures in the locality.

Obviously, both species (perhaps this is also the case with Hesionides arenaria, see Fig. 8) exhibit seasonspecific capacity adaptation of their uptake system. In the terminology of Christophersen (1967) the pattern of Nematoplana coelogynoporoides is an almost ideal compensation', the pattern of Trilobodrilus axi a 'supraoptimal compensation'. In this way the uptake system can provide the animals with a more or less identical amount of amino acids, independent of the environmental temperature. Also, a shortage of particulate food and even of dissolved nutrients in winter (Jørgensen, 1979) could be compensated for by increased uptake of dissolved substances. This phenomenon, however, is unlikely to be universal among marine invertebrates; in sublittoral living Phoronis psammophila inhabiting $5 \mathrm{~m}$ deep water, Emig and Thouveny (1976) found the opposite to be true: a concentration factor (internal concentration/ external concentration) 5 times higher in summer than in winter. Possibly, the season-specific regulation of the uptake system described here represents a special physiological adaptation of some interstitial organisms from temperate tidal beaches with considerable seasonal temperature oscillations. Such characteristic could then be added to the long list of morphological and biological lebensformmerkmale (Ax, 1969), by which these animals are adapted to the interstitial biotope of sandy, littoral sediments. This hypothesis should encourage further investigations on the influence of long-term adaptation prior to experiments.

Acknowledgements. We would like to express our thanks to Professor Dr. P. Ax for financial support and continuous encouragement, Professor Dr. U. Eberhardt and the staff of the Zentrales Isotopenlabor der Universität Göttingen for kindly helping and making available the facilities of the laboratory, Dr. Ingeborg Lang, Professor Dr. R. Hardeland and Dr. V. Ehrhardt for various technical advice and valuable discussion, and Dr. K. Reise for sending the animals to Göttingen. R. v. Sivers kindly prepared the drawings.

\section{LITERATURE CITED}

Ahearn, G. A., Gomme, J. (1975). Transport of exogenous Dglucose by the integument of a polychaete worm (Nereis diversicolor Müller). J. exp. Biol. 62: 243-264

Ax, P. (1969). Populationsdynamik, Lebenszyklen und Fortpflanzungsbiologie der Mikrofauna des Meeressandes. Verh. dt. zool. Ges. Innsbruck 1968: 66-113

Beckmann, J. (1972). Tagesrhythmische Synthese der sauren Kernproteine in der Leber adulter Ratten. Diplomarbeit, Universität Göttingen

Bedini, C., Papi, F. (1974). Fine structure of turbellarian epidermis. In: Riser, N. W., Morse, M. P. (eds) Biology of the Turbellaria. McGraw-Hill, New York, pp. 108-147

Bohling, H. (1970). Untersuchungen über freie gelöste Aminosäuren in Meerwasser. Mar. Biol. 6: 213-255

Bohling, H. (1972). Gelöste Aminosäuren im Oberflächenwasser der Nordsee bei Helgoland: Konzentrationsveränderungen in Sommer 1970. Mar. Biol. 16: 218-309

Chien, P. K., Stephens, G. C., Healey, P. L. (1972). The role of ultrastructure and physiological differentiation of epithelia in amino acid uptake by the bloodworm Glycera. Biol. Bull. mar. biol. Lab., Woods Hole 142: 219-235

Christophersen, J. (1967). Adaptive temperature responses of microorganisms. In: Prosser, C. L. (ed.) Molecular mechanisms of temperature adaption. Am. Ass. Advmt Sci., Washington, pp. 327-348

Clark, N. E., Jackson, G. A., North, W. J. (1972). Dissolved free amino acids in southern California coastal waters. Limnol. Oceanogr. 17: 749-758

Dawson, R., Pritchard, R. G. (1978). The determination of $\alpha$ amino acids in seawater using a fluorimetric analysis. Mar. Chem. 6: 27-40

Dörjes, J. (1968). Die Acoela (Turbellaria) der deutschen Nordseeküste und ein neues System der Ordnung. Z. zool. Syst. Evolutionsforsch. 6: 56-452

Emig, C. C., Thouveny, Y. (1976). Absorption directe d'un acide aminé par Phoronis psammophila. Mar. Biol. 37 : $69-73$

Faubel, A. (1976). Populationsdynamik und Lebenszyklen interstitieller Acoela und Macrostomida (Turbellaria). Mikrofauna Meeresboden 56: 1-107

Gyllenberg, G., Lundqvist, G. (1978). Utilization of dissolved glucose by two copepod species. Ann. Zool. Fennici 15: 323-327

Hartwig, E. (1973). Die Ciliaten des Gezeiten-Sandstrandes der Nordseeinsel Sylt, II. Okologie. Mikrofauna Meeresboden 21: 1-171

Henrichs, S. M., Farrington, J. W. (1979). Amino acids in interstitial waters of marine sediments. Nature, Lond. 279: 319-321

Jørgensen, C. B. (1976). August Pütter, August Krogh, and modern ideas on the use of dissolved organic matter in aquatic environments. Biol. Rev. 51: 291-328

Jørgensen, N. O. G. (1979). Annual variation of dissolved free primary amines in estuarine water and sediment. Oecologia (Berl.) 40: 207-217

Lasserre, P., Renaud-Mornant, J. (1973). Resistance and respiratory physiology of intertidal meiofauna to oxygendeficiency. Neth. J. Sea Res. 7: 290-302

Lee, C., Bada, J. L. (1977). Dissolved amino acids in the equatorial Pacific, the Sargasso Sea, and Biscayne Bay. Limnol. Oceanogr. 22: 502-510

Meineke, T., Westheide, W. (1979). Gezeitenabhängige Wanderungen der Interstitialfauna in einem Sandstrand der Insel Sylt (Nordsee). Mikrofauna Meeresboden 75: 203-236 
Mielke, W. (1976). Ókologie der Copepoda eines Sandstrandes der Nordseeinsel Sylt. Mikrofauna Meeresboden. 59: $1-86$

North, B. B. (1975). Primary amines in California coastal waters: Utilization by phytoplancton. Limnol. Oceanogr. 20: $20-27$

Rieger, R. M., Rieger, G. E. (1976). Fine structure of the archiannelid cuticle and remarks on the evolution of the cuticle within the spiralia. Acta zool. (Stockh.) 57: 53-68

Salvat, B., Renaud-Mornant, J. (1969). Etude écologique du macrobenthos et du meiobenthos d'un fond sableux du Lagon de Mururoa (Tuamotu - Polynésie). Cah. Pacif. 13: $159-179$

Schell, D. M. (1974). Uptake and regeneration of free amino acids in marine waters of Southeast Alaska. Limnol. Oceanogr. 19: 260-270

Schlichter, D. (1973). Ernährungsphysiologische und ökologische Aspekte der Aufnahme in Meerwasser gelöster Aminosäuren durch Anemonia sulcata (Coelenterata, Anthozoa). Oecologia (Berl.) 2: 315-350

Schlichter, D. (1974). Der Einfluß physikalischer und chemischer Faktoren auf die Aufnahme in Meerwasser gelöster Aminosäuren durch Aktinien. Mar. Biol. 25: $279-290$

Schmidt, P. (1968). Die quantitative Verteilung und Populationsdynamik des Mesopsammons am Gezeitenstrand der Nordseeinsel Sylt. I. Faktarengefüge und biologische Gliederung des Lebensraumes. Int. Revue ges. Hydrobiol. 53: 723-779

Schmidt, P. (1969). Die quantitative Verteilung und Populationsdynamik des Mesopsammons am GezeitenSandstrand der Nordseeinsel Sylt. II. Quantitative Verteilung und Populationsdynamik einzelner Arten. Int. Revue ges. Hydrobiol. 54 : 95-174

Schmitt, E. (1955). Über das Verhalten von Süßwasserplanarien (Planaria gonocephala Dugès und Planaria lugubris O. Schmidt) in Brackwasser. Kieler Meeresforsch. 11: $48-58$

Sepers, A. B. (1977). The utilization of dissolved organic compounds in aquatic environments. Hydrobiologia 52: 39-54

Shick, J. M. (1973). Effects of salinity and starvation on the uptake of dissolved glycine by Aurelia aurita polyps. Biol. Bull. mar. biol. Lab., Woods Hole 144: 172-179

Shick, J, M. (1975). Uptake and utilization of dissolved glycine by Aurelia aurita scyphistomae: Temperature effects on the uptake process; nutritional role of dissolved amino acids. Biol. Bull, mar, biol. Lab., Woods Hole 148: 117-140

Siebers, D. (1976). Absorption of neutral and basic amino acids across the body surface of two annelid species. Helgoländer wiss. Meeresunters. 28: 456-466

Siebers, D., Bulnheim, H.-P. (1977). Salinity dependence, uptake kinetics, and specificity of amino acid absorption across the body surface of the oligochaete annelid Enchytraeus albidus. Helgolander wiss. Meeresunters. 29: 473-592

Sopott, B. (1973). Jahreszeitliche Verteilung und Lebenszyklen der Proseriata (Turbellaria) eines Sandstrandes der Nordseeinsel Sylt. Mikrofauna Meeresboden 15: 1-106
Southward, A. J., Southward, E. C., Brattegard, T., Bakke, T. (1979). Further experiments on the value of dissolved organic matter as food for Siboglinum fiordicum (Pogonophora). J. mar. biol. Ass. U. K. 59: 133-148

Stephens, G. C. (1963). Uptake of organic material by aquatic invertebrates, II. Accumulation of amino acids by the bamboo worm, Clymenella torquata. Comp. Biochem. Physiol. 10: 191-209

Stephens, G. C. (1964). Uptake of organic material by aquatic invertebrates, III. Uptake of glycine by brackish water annelids. Biol. Bull. mar. biol. Lab., Woods Hole 126: 150-162

Stephens, G. C. (1975). Uptake of naturally occurring primary amines by marine annelids. Biol. Bull. mar. biol. Lab., Woods Hole 149: 397-407

Stephens, G. C., Schinske, R. A. (1961). Uptake of amino acids by marine invertebrates. Limnol. Oceanogr. 6: 175-181

Stephens, G. C., Virkar, R. A. (1966). Uptake of organic material by aquatic invertebrates, IV. The influence of salinity on the uptake of amino acids by the brittle star, Ophiactis arenosa. Biol. Bull. mar. biol. Lab., Woods Hole 131: 172-185

Stephens, G. C., Volk, M. J., Wright, S. H., Backlund, P. S. (1978). Transepidermal accumulation of naturally occurring amino acids in the sand dollar, Dendraster excentricus. Biol. Bull. mar. biol. Lab., Woods Hole 154: 335-347

Stewart, M. G. (1979). Absorption of dissolved organic nutrients by marine invertebrates. Oceanogr. mar. biol. A. Rev. 17: 163-192

Stripp, K. (1969). Jahreszeitliche Fluktuationen von Makrofauna und Meiofauna in der Helgoländer Bucht. Veröff. Inst. Meeresforsch. Bremerh. 12: 65-94

Taylor, A. G. (1969). The direct uptake of amino acids and other small molecules from sea water by Nereis virens Sars. Comp. Biochem. Physiol 29: 243-250

Virkar, R. A. (1963). Amino acids in the economy of the sipunculid worm, Golfingia gouldii. Biol. Bull. mar. biol. Lab., Woods Hole 125: 396-397

Wainwright, W. W., Anderson, E. D., Hammer, P. C., Lehman, C. A. (1954). Simplified autoradiography exposure calculation. Nucleonics 12: 19-21

West, B., de Burgh, M., Jeal, F. (1977). Dissolved organics in the nutrition of benthic invertebrates. In: Keegan, B. F., Ceidigh, P. O., Boaden, P. G. S. (eds) Biology of benthic organisms. Pergamon, Oxford and New York, pp. 587-593

Westheide, W. (1967). Monographie der Gattungen Hesionides Friedrich und Microphthalmus Mecznikow (Polychaeta, Hesionidae). Ein Beitrag zur Organisation und Biologie psammobionter Polychaeten. Z.Morph. Tiere 61: $1-159$

Westheide, W. (1968). Zur quantitativen Verteilung von Bakterien und Hefen in einem Gezeitenstrand der Nordseeküste. Mar. Biol. 1: 336-347

Westheide, W., Rieger, R. (1978). Cuticle ultrastructure of hesionid polychaetes (Annelida). Zoomorphologie 91: $1-18$

Westheide, W., Schmidt, P. (1974). Trilobodrilus axi (Polychaeta). Nahrungsaufnahme und Fortpflanzung. Encyclopaedia Cinematographica, Film E 1955, Begleitveröffentlichunq, $1-12$ 